\begin{tabular}{|l|l|l||}
\hline \multicolumn{2}{|c|}{ PublisherInfo } \\
\hline \hline PublisherName & $:$ & BioMed Central \\
\hline \hline PublisherLocation & $:$ & London \\
\hline \hline PublisherImprintName & $:$ & BioMed Central \\
\hline \hline
\end{tabular}

\title{
DNA repair within nucleosomes
}

\begin{tabular}{|l|l|l||}
\hline \multicolumn{2}{|c|}{ ArticleInfo } \\
\hline \hline ArticleID & $:$ & 3858 \\
\hline \hline ArticleDOI & $:$ & $10.1186 /$ gb-spotlight-20001211-02 \\
\hline \hline ArticleCitationID & $:$ & spotlight-20001211-02 \\
\hline \hline ArticleSequenceNumber & $:$ & 295 \\
\hline \hline ArticleCategory & $:$ & Research news \\
\hline \hline ArticleFirstPage & $:$ & 1 \\
\hline \hline ArticleLastPage & $:$ & 2 \\
\hline \hline & & RegistrationDate : 2000-12-11 \\
ArticleHistory & $:$ & OnlineDate $\quad 2000-12-11$ \\
\hline \hline ArticleCopyright & $:$ & BioMed Central Ltd2000 \\
\hline \hline ArticleGrants & $:$ & \\
\hline \hline ArticleContext & $:$ & 130591111 \\
\hline \hline
\end{tabular}




\section{Jonathan Weitzman}

Email: jonathanweitzman@hotmail.com

DNA lesions are repaired by a cut-and-remove process called nucleotide excision repair. An in vitro biochemically defined system has been developed in which six repair factors are sufficient to excise damage from naked DNA. In the December Molecular and Cellular Biology, Hara et al. use this system to examine the effect of DNA organization into nucleosome structures on the DNA repair process ( $\mathrm{Mol}$ Cell Biol 2000, 20:9173-9181). A nucleosome structure was assembled by mixing human histone proteins with a 136 bp DNA fragment containing a (6-4) photoproduct lesion. The nucleosome was then used as a damaged substrate using the reconstituted human excision assay or human whole-cell extracts. DNA damage within the nucleosome core was repaired at about $10 \%$ the rate of naked DNA. Hara et al. also showed that there are no additional accessibility factors that are specific for nucleotide excision repair. Hence, chromatin compaction presents a significant impediment to the human excision nuclease.

\section{References}

1. DNA excision repair.

2. Molecular and Cellular Biology, [http://www.intl-mcb.asm.org]

This PDF file was created after publication. 